\title{
Developing and Testing Model for Investment Risk Assessment in Agriculture
}

\author{
Zaporozhtseva Liudmila Anatolievna \\ Chair of finance and credit \\ Voronezh state agrarian university \\ Voronezh, Russia \\ ludan23@yandex.ru
}

\author{
Sabetova Tatiana Vladislavovna \\ Chair of management and marketing in agro-industrial \\ complex \\ Voronezh state agrarian university \\ Voronezh, Russia \\ tsabetova@mail.ru
}

\author{
Tkacheva Julia Viktorovna \\ Chair of finance and credit \\ Voronezh state agrarian university \\ Voronezh, Russia \\ julchen19@yandex.ru
}

\begin{abstract}
The urgency of the present study is due to the absence of any reliable method for investment risk assessment in agribusiness which impedes attracting and control of investment processes in this sector of economy. The article presents a new approach to modelling investment risk assessment applicable for agricultural companies. Determination of the financial stability level of a company is the core of the matrix model. This is a unique system of indicators that continuously reflect the operation quality and methods. It provides an assessment of the results of decisions made and actions of managers at various levels, the measure of control and management of assets, their sources, expenses and incomes of a company. The suggested procedure may also be of use for the Department of Agrarian Policy and Business in providing scientific and methodological support for ranking agricultural companies to identify the risk of investing in their activities.
\end{abstract}

Keywords - risk of investment, agriculture, matrix model, the enterprise

\section{INTRODUCTION}

The five-year National programme of agriculture development and food agricultural product market regulation for 2008-2012 had long been finished and replaced by new priority National programme for 20132020 was launched covering the whole variety of agroindustrial complex development directions, food security of the country, sustainable development of rural areas.

Implementation of the former Programme together with the Priority national programme of agro-industrial complex development took 519.1 bln rubles from the National budget. As a result, the special-purpose financial resources in Voronezh region twice exceeded the total net profit of the whole agrarian sector. Actually, in Voronezh region, as well as throughout the country, these programmes subsidised both agriculture development projects and this sector's economic losses. Within the implementation of the latter Programme, no considerable change of such situation is foreseen.

The Department of agrarian policy of Voronezh region faces the problem of providing financial resources for agricultural companies of the region, which can be solved through attracting private investments. However, considerable obstacle lies in the absence of reliable procedures for risk assessment in case of investments into agrarian sector and company ranging on the unified scale of risk, from the less to the most risky one, and thus least attractive for investments.

\section{The SugGested Procedure}

The matrix model offered by the authors can become an effective tool for investment risk express assessment in the agrarian sector, as it simultaneously reflects the financial operation of the company in question, gives a qualitative description of the operational results, and helps in understanding of the effort put in to achieve these results.

Based on the idea of G. Uvarova and V. Antashov [1], associated with the formation of a matrix model for evaluating the results of production and economic activities, but without linking them to financial sustainability, we have built a matrix model for another purpose, tracking the changes in the financial sustainability of a company with access to an integral index.

A comprehensive change in the level of financial stability of organizations was selected as the criterion of the express assessment of investment risk for companies of the agrarian sector [2][3]. We defined the indicators included in 
the matrix model based on the characteristics of financial sustainability, taking into account three factors (sufficiency of equity and borrowed capital, acceptable level of monetary funds, resource use efficiency [4]), based on the principle of the 'golden economic rule': "Pre-tax profit growth rate > Sales growth rate $>$ Asset growth rate $>100 \%$, as well as the concept of operational analysis "cost - sale - profit".

The model is based on the principle of hierarchical maximization of initial indicators [5][6]: net profit should grow faster than the profit from product sales, profit from product sales - faster than revenue, revenue - faster than cost, and finally, cost - faster than static assets and their sources (increasing asset turnover) [7]. However, the most important thing is that the model characterizes the ability to track changes in the investment risk according to the condition: the higher the level of financial stability, the lower the risk of investment income non-receipt and vice versa.

The authors' matrix (square table) represents the financial activity of a company in the form of an entry-exit model [8]. There are 13 standard indicators (usually used for determination of the financial stability of a company) set at the 'entrance' that can be found in the financial statements, and 177 indicators obtained at the 'output' (see Table 1).

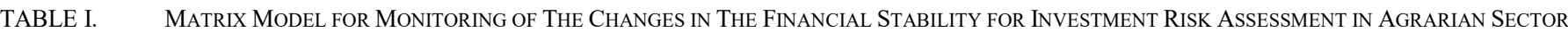

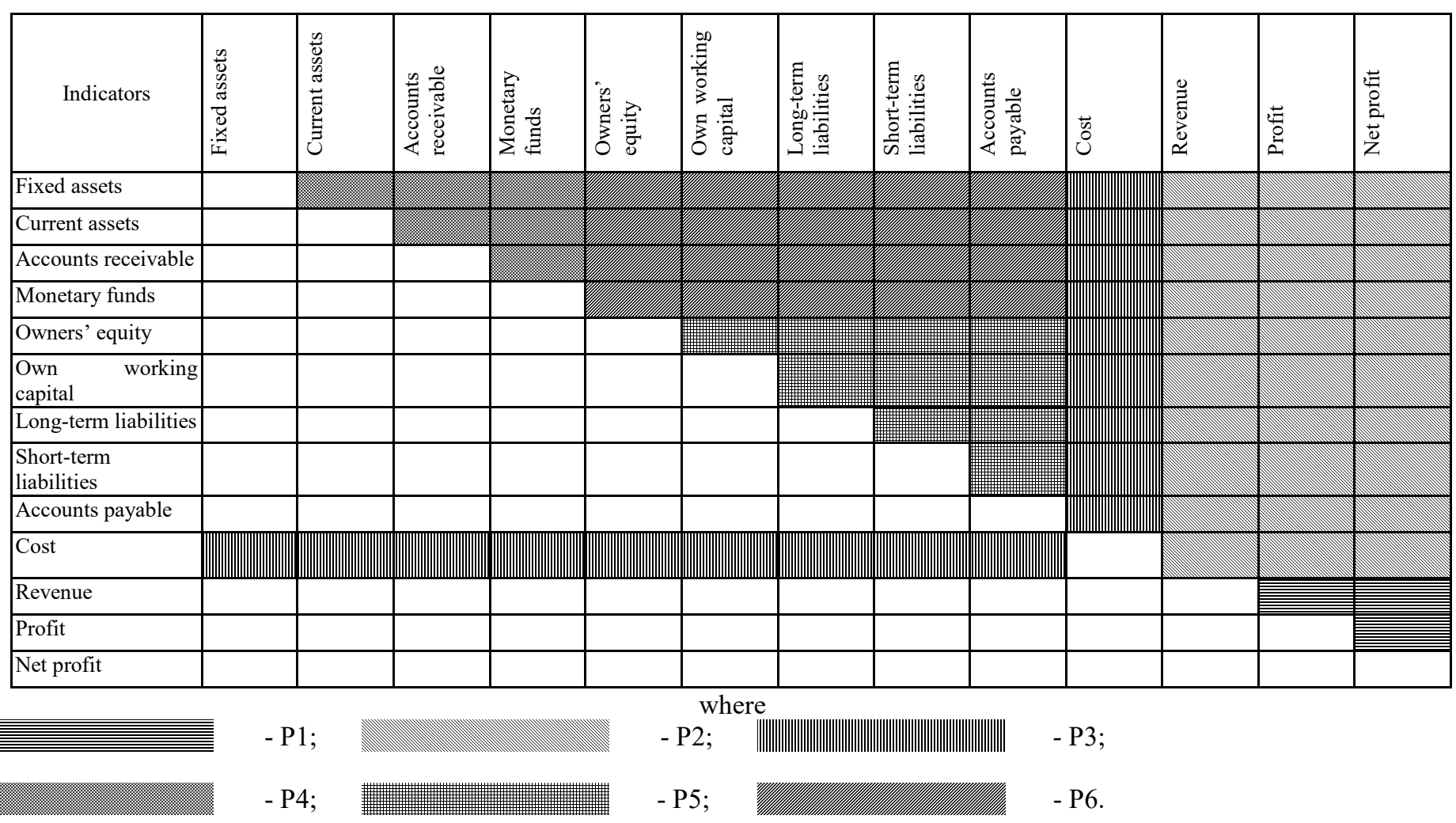

The elements of the matrix are relative indicators obtained by dividing the data of the reporting period to the data of the basis period according to the results of the company's activities (income) and expenses, as well as by assets and sources of their formation [9]. To track the changes in the financial sustainability of a company, a complex of interrelated indicators is calculated in the matrix, obtained by correlating the figures at the intersection in the numerator of the table (horizontally) and its denominator (vertically). On this basis one can give judgement on the level of financial stability of the company.

To form the particular conclusions concerning the financial condition, generalized block and integrated estimates are used, which are calculated as arithmetic mean values of the indicators included in the block in question.
They describe the strength of the relationship between the final results, incomes and expenses of the company, the assets and their sources, and are located above the main diagonal of the matrix (highlighted in various shades in Table 1). The exception is the block of interrelation of expenses with assets and their sources, located below the main diagonal of the matrix (A3). Each of these blocks has its own economic interpretation.

\section{The Procedure TESTING}

The authors reflected the interpretation of the values of the matrix model indicators for assessing the investment risk in the agrarian sector, using the example of agricultural artel 'Rassvet' in Pavlovsk district of Voronezh region, having 
previously calculated them based of the financial statements

of this agricultural company (see Tables 2 and 3):

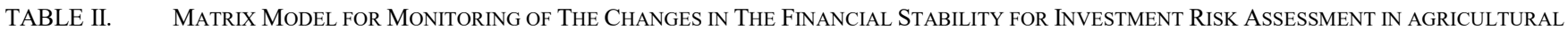
ARTEL ‘RASSVET’ IN PAVLOVSK DISTRICT OF VORONEZH REGION

\begin{tabular}{|c|c|c|c|c|c|c|c|c|c|c|c|c|c|}
\hline Indicators & $\begin{array}{l}\text { Fixed } \\
\text { assets } \\
\text { (FA) }\end{array}$ & $\begin{array}{c}\text { Current } \\
\text { assets } \\
\text { (CA) }\end{array}$ & $\begin{array}{l}\text { Accounts } \\
\text { receivable } \\
\text { (AR) }\end{array}$ & \begin{tabular}{|c|} 
Monetary \\
funds (MF)
\end{tabular} & $\begin{array}{c}\text { Owners' } \\
\text { equity } \\
\text { (OE) }\end{array}$ & $\begin{array}{c}\text { Own } \\
\text { working } \\
\text { capital } \\
(\text { OWC }) \\
\end{array}$ & $\begin{array}{c}\text { Long-term } \\
\text { liabilities } \\
\text { (LTL) }\end{array}$ & $\begin{array}{c}\text { Short-term } \\
\text { liabilities } \\
\text { (STL) }\end{array}$ & $\begin{array}{c}\text { Accounts } \\
\text { payable } \\
\text { (AP) }\end{array}$ & \begin{tabular}{|c|} 
Cost of the \\
sold products \\
(Cost)
\end{tabular} & $\begin{array}{c}\text { Sales } \\
\text { revenue }\end{array}$ & $\begin{array}{l}\text { Profit on } \\
\text { sales }\end{array}$ & Net profit (Np) \\
\hline & 1.130 & 1.308 & 0.471 & 0.807 & 1.363 & 1.183 & 0.235 & 1.542 & 1.542 & 1.053 & 1.267 & 1.734 & 2.844 \\
\hline $\begin{array}{|ll|}\begin{array}{l}\text { Fixed } \\
\text { (FA) }\end{array} & \text { assets } \\
\end{array}$ & & $\begin{array}{c}\text { Ratio CA } \\
\text { and FA }\end{array}$ & $\begin{array}{c}\text { Ratio AR and } \\
\text { FA }\end{array}$ & \begin{tabular}{|c|} 
Ratio MF and \\
FA
\end{tabular} & $\begin{array}{l}\text { Ratio OE } \\
\text { and FA }\end{array}$ & $\begin{array}{c}\text { Ratio OWC } \\
\text { and FA }\end{array}$ & \begin{tabular}{|c|} 
Long-term \\
investment \\
structure rate
\end{tabular} & $\begin{array}{c}\text { Ratio STL } \\
\text { and FA }\end{array}$ & \begin{tabular}{|c|} 
Ratio AP and \\
FA
\end{tabular} & $\begin{array}{c}\text { Ratio Cost and } \\
\text { FA }\end{array}$ & $\begin{array}{c}\text { Fixed asset } \\
\text { turnover } \\
\text { ratio }\end{array}$ & \begin{tabular}{|c|}
$\begin{array}{c}\text { Return on the } \\
\text { fixed assets }\end{array}$ \\
\end{tabular} & $\begin{array}{l}\text { Return on the } \\
\text { fixed assets } \\
\text { calculated from } \\
\text { the net profit }\end{array}$ \\
\hline 1.130 & * & 1.158 & 0.417 & 0.714 & 1.207 & 1.048 & 0.208 & 1.365 & 1.365 & 0.932 & 1.121 & 1.535 & 2.518 \\
\hline \begin{tabular}{|l|}
$\begin{array}{l}\text { Current } \\
\text { (CA) }\end{array}$ \\
\end{tabular} & \begin{tabular}{|c|} 
Ratio FA \\
and CA
\end{tabular} & $\mathbf{P 4} \rightarrow$ & $\begin{array}{c}\text { Ratio AR and } \\
\text { CA }\end{array}$ & \begin{tabular}{|c|} 
Ratio MF and \\
CA
\end{tabular} & $\begin{array}{c}\text { Ratio } \mathrm{OE} \\
\text { and } \mathrm{CA}\end{array}$ & \begin{tabular}{|c|} 
Own \\
working \\
capital \\
turnover ratio \\
\end{tabular} & $\begin{array}{c}\text { Ratio LTL } \\
\text { and CA }\end{array}$ & $\begin{array}{c}\text { Ratio STL } \\
\text { and CA }\end{array}$ & \begin{tabular}{|c|} 
Ratio AP and \\
CA
\end{tabular} & $\begin{array}{c}\text { Ratio Cost and } \\
\text { CA }\end{array}$ & $\begin{array}{c}\text { Current asset } \\
\text { turnover } \\
\text { ratio }\end{array}$ & \begin{tabular}{|l|} 
Return on the \\
current assets
\end{tabular} & $\begin{array}{l}\text { Return on the } \\
\text { current assets } \\
\text { calculated from } \\
\text { the net profit }\end{array}$ \\
\hline 1.308 & 0.864 & * & 0.360 & 0.617 & 1.042 & \begin{tabular}{l|l}
0.905 &
\end{tabular} & 0.180 & 1.179 & 1.179 & 0.805 & 0.968 & 1.326 & 2.175 \\
\hline \begin{tabular}{|l|} 
Accounts \\
receivable \\
(AR)
\end{tabular} & \begin{tabular}{|c|} 
Ratio FA \\
and AR
\end{tabular} & $\begin{array}{c}\text { Ratio CA } \\
\text { and } \mathrm{AR}\end{array}$ & & \begin{tabular}{|c|} 
Ratio MF and \\
AR
\end{tabular} & $\begin{array}{c}\text { Ratio } \mathrm{OE} \\
\text { and } \mathrm{AR}\end{array}$ & $\begin{array}{c}\text { Ratio OWC } \\
\text { and } \mathrm{AR}\end{array}$ & $\begin{array}{l}\text { Ratio LTL } \\
\text { and AR }\end{array}$ & $\begin{array}{c}\text { Ratio STL } \\
\text { and AR }\end{array}$ & $\begin{array}{c}\text { Ratio AP and } \\
\text { AR }\end{array}$ & $\begin{array}{c}\text { Ratio Cost and } \\
\text { AR }\end{array}$ & $\begin{array}{c}\text { Accounts } \\
\text { receivable } \\
\text { turnover } \\
\text { ratio }\end{array}$ & \begin{tabular}{|c|} 
Return on the \\
accounts \\
receivable
\end{tabular} & $\begin{array}{l}\text { Return on the } \\
\text { accounts } \\
\text { receivable } \\
\text { calculated from } \\
\text { the net profit }\end{array}$ \\
\hline 0.471 & 2.398 & 2.776 & * & 1.713 & 2.894 & 2.512 & 0.499 & 3.273 & 3.273 & 2.234 & 2.689 & 3.681 & 6.038 \\
\hline $\begin{array}{l}\text { Monetary } \\
\text { funds (MF) }\end{array}$ & \begin{tabular}{|l|} 
Ratio FA \\
and MF
\end{tabular} & $\begin{array}{l}\text { Ratio CA } \\
\text { and MF }\end{array}$ & $\begin{array}{c}\text { Ratio AR and } \\
\text { MF }\end{array}$ & P6 $\rightarrow$ & $\begin{array}{l}\text { Ratio OE } \\
\text { and MF }\end{array}$ & $\begin{array}{l}\text { Ratio OWC } \\
\text { and MF }\end{array}$ & $\begin{array}{c}\text { Ratio LTL } \\
\text { and MF }\end{array}$ & $\begin{array}{l}\text { Ratio STL } \\
\text { and MF }\end{array}$ & \begin{tabular}{|c|} 
Ratio AP and \\
MF
\end{tabular} & $\begin{array}{c}\text { Ratio Cost } \\
\text { и MF }\end{array}$ & $\begin{array}{l}\text { Monetary } \\
\text { fund } \\
\text { turnover } \\
\text { ratio }\end{array}$ & \begin{tabular}{|c|}
$\begin{array}{c}\text { Return on the } \\
\text { monetary } \\
\text { funds }\end{array}$ \\
\end{tabular} & $\begin{array}{l}\text { Return on the } \\
\text { monetary funds } \\
\text { calculated from } \\
\text { the net profit }\end{array}$ \\
\hline 0.807 & 1.400 & 1.621 & 0.584 & $*$ & 1.690 & 1.467 & 0.291 & 1.911 & 1.911 & 1.305 & 1.570 & 2.149 & 3.526 \\
\hline $\begin{array}{l}\text { Owners' } \\
\text { equity (OE) }\end{array}$ & $\begin{array}{l}\text { Equity } \\
\text { ratio }\end{array}$ & $\begin{array}{c}\text { Ratio CA } \\
\text { and } \mathrm{OE}\end{array}$ & $\begin{array}{c}\text { Ratio AR and } \\
\text { OE }\end{array}$ & \begin{tabular}{|c|} 
Ratio MF and \\
OE
\end{tabular} & & $\begin{array}{l}\text { Current } \\
\text { assets to } \\
\text { equity ratio }\end{array}$ & \begin{tabular}{|c|}
$\begin{array}{c}\text { Financial risk } \\
\text { ratio }\end{array}$ \\
\end{tabular} & $\begin{array}{l}\text { Ratio STL } \\
\text { and } \mathrm{OE}\end{array}$ & \begin{tabular}{|c|} 
Ratio AP and \\
OE
\end{tabular} & $\begin{array}{c}\text { Ratio COST and } \\
\text { OE }\end{array}$ & $\begin{array}{c}\text { Owners' } \\
\text { equity } \\
\text { turnover } \\
\text { ratio } \\
\end{array}$ & ROE & $\begin{array}{l}\text { ROE calculated } \\
\text { from the net profit }\end{array}$ \\
\hline 1.363 & 0.828 & 0.959 & 0.346 & 0.592 & * & 0.868 & 0.172 & 1.131 & 1.131 & 0.772 & 0.929 & 1.272 & 2.086 \\
\hline \begin{tabular}{|l|} 
Own working \\
capital $($ OWC $)$
\end{tabular} & \begin{tabular}{|c|} 
Ratio FA \\
and \\
OWC
\end{tabular} & $\begin{array}{l}\text { Ratio CA } \\
\text { and OWC }\end{array}$ & $\begin{array}{l}\text { Ratio AR and } \\
\text { OWC }\end{array}$ & $\begin{array}{c}\text { Ratio MF and } \\
\text { OWC }\end{array}$ & $\begin{array}{l}\text { Ratio OE } \\
\text { and OWC }\end{array}$ & & $\begin{array}{l}\text { Ratio LTL } \\
\text { and OWC }\end{array}$ & $\begin{array}{l}\text { Ratio STL } \\
\text { and OWC }\end{array}$ & \begin{tabular}{|c|} 
Ratio $\mathrm{AP}$ and \\
$\mathrm{OWC}$
\end{tabular} & $\begin{array}{c}\text { Ratio Cost and } \\
\text { OWC }\end{array}$ & $\begin{array}{c}\text { Own } \\
\text { working } \\
\text { capital } \\
\text { turnover } \\
\text { ratio }\end{array}$ & \begin{tabular}{|c|}
$\begin{array}{c}\text { Return on the } \\
\text { own working } \\
\text { capital }\end{array}$ \\
\end{tabular} & $\begin{array}{l}\text { Return on the own } \\
\text { working capital } \\
\text { calculated from } \\
\text { the net profit }\end{array}$ \\
\hline 1.183 & 0.955 & 1.105 & 0.398 & 0.682 & 1.152 & * & 0.199 & 1.303 & 1.303 & 0.890 & 1.071 & 1.465 & 2.404 \\
\hline $\begin{array}{l}\text { Long-term } \\
\text { liabilities } \\
\text { (LTL) }\end{array}$ & \begin{tabular}{|l|} 
Ratio FA \\
and LTL
\end{tabular} & $\begin{array}{l}\text { Ratio CA } \\
\text { and LTL }\end{array}$ & $\begin{array}{l}\text { Ratio AR and } \\
\text { LTL }\end{array}$ & \begin{tabular}{|c|} 
Ratio MF and \\
LTL
\end{tabular} & $\begin{array}{l}\text { Financial } \\
\text { stability } \\
\text { index }\end{array}$ & $\begin{array}{l}\text { Ratio OWC } \\
\text { and LTL }\end{array}$ & P5 $\rightarrow$ & $\begin{array}{l}\text { Ratio STL } \\
\text { and LTL }\end{array}$ & \begin{tabular}{|c|} 
Ratio AP and \\
LTL
\end{tabular} & $\begin{array}{c}\text { Ratio Cost and } \\
\text { LTL }\end{array}$ & $\begin{array}{c}\text { Long-term } \\
\text { liability } \\
\text { turnover } \\
\text { ratio } \\
\end{array}$ & \begin{tabular}{|c|} 
Return on \\
long-term debt
\end{tabular} & $\begin{array}{l}\text { Return on long- } \\
\text { term debt } \\
\text { calculated from } \\
\text { the net profit } \\
\end{array}$ \\
\hline 0.235 & 4.806 & 5.565 & 2.004 & 3.433 & 5.801 & 5.034 & * & 6.560 & 6.560 & 4.479 & 5.389 & 7.377 & 12.102 \\
\hline $\begin{array}{l}\text { Short-term } \\
\text { liabilities } \\
\text { (STL) }\end{array}$ & \begin{tabular}{|l|} 
Ratio FA \\
and STL
\end{tabular} & $\begin{array}{l}\text { Current } \\
\text { ratio }\end{array}$ & $\begin{array}{l}\text { Ratio AR and } \\
\text { STL }\end{array}$ & \begin{tabular}{|c|} 
Absolute \\
liquidity ratio
\end{tabular} & $\begin{array}{l}\text { Ratio OE } \\
\text { and STL }\end{array}$ & $\begin{array}{c}\text { Ratio OWC } \\
\text { and STL }\end{array}$ & $\begin{array}{l}\text { Ratio LTL } \\
\text { and STL }\end{array}$ & & $\begin{array}{c}\text { Share of AP } \\
\text { in STL }\end{array}$ & $\begin{array}{c}\text { Ratio Cost and } \\
\text { STL }\end{array}$ & $\begin{array}{c}\text { Short-term } \\
\text { liability } \\
\text { turnover } \\
\text { ratio } \\
\end{array}$ & $\begin{array}{l}\text { Return on } \\
\text { short-term } \\
\text { debt }\end{array}$ & $\begin{array}{l}\text { Return on short- } \\
\text { term debt } \\
\text { calculated from } \\
\text { the net profit }\end{array}$ \\
\hline 1.542 & 0.733 & 0.848 & 0.306 & 0.523 & 0.884 & 0.767 & 0.152 & * & 1.000 & 0.683 & 0.822 & 1.125 & 1.845 \\
\hline $\begin{array}{l}\text { Accounts } \\
\text { payable (AP) }\end{array}$ & \begin{tabular}{|c|} 
Ratio FA \\
and AP
\end{tabular} & $\begin{array}{c}\text { Ratio CA } \\
\text { and } \mathrm{AP}\end{array}$ & $\begin{array}{c}\text { Ratio AR and } \\
\mathrm{AP}\end{array}$ & \begin{tabular}{|c|} 
Ratio MF and \\
AP
\end{tabular} & Ratio OE AP & $\begin{array}{c}\text { Ratio OWC } \\
\text { and AP }\end{array}$ & $\begin{array}{c}\text { Ratio LTL } \\
\text { and AP }\end{array}$ & $\begin{array}{c}\text { Ratio STL } \\
\text { and AP }\end{array}$ & & $\begin{array}{c}\text { Ratio Cost and } \\
\text { AP }\end{array}$ & $\begin{array}{l}\text { Accounts } \\
\text { payable } \\
\text { turnover } \\
\text { ratio } \\
\end{array}$ & \begin{tabular}{|c|} 
Return on the \\
accounts \\
payable
\end{tabular} & $\begin{array}{l}\text { Return on the } \\
\text { accounts payable } \\
\text { calculated from } \\
\text { the net profit }\end{array}$ \\
\hline 1.542 & 0.733 & 0.848 & 0.306 & 0.523 & 0.884 & 0.767 & 0.152 & 1.000 & * & 0.683 & 0.822 & 1.125 & 1.845 \\
\hline \begin{tabular}{|l|} 
Cost of the \\
sold products \\
(Cost) \\
\end{tabular} & \begin{tabular}{|c|} 
Ratio FA \\
and cost
\end{tabular} & $\begin{array}{l}\text { Ratio CA } \\
\text { and Cost }\end{array}$ & $\begin{array}{l}\text { Ratio AR and } \\
\text { Cost }\end{array}$ & \begin{tabular}{|c|} 
Ratio MF and \\
Cost
\end{tabular} & $\begin{array}{l}\text { Ratio OE } \\
\text { and Cost }\end{array}$ & $\begin{array}{c}\text { Ratio OWC } \\
\text { and Cost }\end{array}$ & $\begin{array}{l}\text { Ratio LTL } \\
\text { and Cost }\end{array}$ & $\begin{array}{l}\text { Ratio STL } \\
\text { and Cost }\end{array}$ & \begin{tabular}{|c|} 
Ratio AP and \\
Cost
\end{tabular} & $\leftarrow \mathbf{P 3}$ & $\begin{array}{l}\text { Return on } \\
\text { cost from } \\
\text { revenue }\end{array}$ & $\begin{array}{l}\text { Sold product } \\
\text { profitability }\end{array}$ & $\begin{array}{c}\text { Sales profitability } \\
\text { calculated from } \\
\text { the net profit } \\
\end{array}$ \\
\hline 1.053 & 1.073 & 1.243 & 0.448 & 0.766 & 1.295 & 1.124 & 0.223 & 1.465 & 1.465 & $\mathbf{P 2} \rightarrow$ & 1.203 & 1.647 & 2.702 \\
\hline Sales revenue & \begin{tabular}{|c|}
$\begin{array}{c}\text { Capital/ } \\
\text { Product } \\
\text { ratio }\end{array}$ \\
\end{tabular} & \begin{tabular}{|c|} 
Ratio CA \\
and revenue
\end{tabular} & $\begin{array}{l}\text { Ratio AR and } \\
\text { revenue }\end{array}$ & $\begin{array}{c}\text { Ratio MF and } \\
\text { revenue }\end{array}$ & \begin{tabular}{|c|} 
Ratio $\mathrm{OE}$ \\
and revenue
\end{tabular} & \begin{tabular}{|l|} 
Ratio OWC \\
and revenue
\end{tabular} & $\begin{array}{c}\text { Ratio LTL } \\
\text { and revenue }\end{array}$ & $\begin{array}{c}\text { Ratio STL } \\
\text { and revenue }\end{array}$ & $\begin{array}{c}\text { Ratio AP and } \\
\text { revenue }\end{array}$ & $\begin{array}{c}\text { Cost per } 1 \text { ruble } \\
\text { of revenue }\end{array}$ & & $\begin{array}{c}\text { Sales } \\
\text { profitability }\end{array}$ & $\begin{array}{l}\text { Sales profitability } \\
\text { calculated from } \\
\text { the net profit }\end{array}$ \\
\hline 1.267 & 0.892 & 1.033 & 0.372 & 0.637 & 1.076 & 0.934 & 0.186 & 1.217 & 1.217 & 0.831 & * & 1.369 & 2.246 \\
\hline Profit on sales & \begin{tabular}{|c|} 
Capital/ \\
Profit \\
ratio \\
\end{tabular} & $\begin{array}{l}\text { Ratio CA } \\
\text { and profit }\end{array}$ & $\begin{array}{l}\text { Ratio AR and } \\
\text { profit }\end{array}$ & \begin{tabular}{|c|} 
Ratio MF and \\
profit
\end{tabular} & $\begin{array}{l}\text { Ratio } \mathrm{OE} \\
\text { and profit }\end{array}$ & $\begin{array}{l}\text { Ratio OWC } \\
\text { and profit }\end{array}$ & $\begin{array}{l}\text { Ratio LTL } \\
\text { and profit }\end{array}$ & $\begin{array}{l}\text { Ratio STL } \\
\text { and profit }\end{array}$ & $\begin{array}{c}\text { Ratio AP and } \\
\text { profit }\end{array}$ & \begin{tabular}{|c|} 
Cost- \\
intensiveness of \\
profit
\end{tabular} & \begin{tabular}{|c|}
$\begin{array}{c}\text { Revenue per } \\
1 \text { ruble of } \\
\text { profit }\end{array}$ \\
\end{tabular} & $\mathbf{P 1} \rightarrow$ & $\begin{array}{l}\text { Ratio } \mathrm{Np} \text { and sales } \\
\text { profit }\end{array}$ \\
\hline 1.734 & 0.651 & 0.754 & 0.272 & 0.465 & 0.786 & 0.682 & 0.136 & 0.889 & 0.889 & 0.607 & 0.731 & * & 1.640 \\
\hline \begin{tabular}{|l|} 
Net profit $(\mathrm{Np})$ \\
\end{tabular} & \begin{tabular}{|c|} 
Capital/ \\
Net Profit \\
ratio \\
\end{tabular} & $\begin{array}{c}\text { Ratio CA } \\
\text { and } \mathrm{Np}\end{array}$ & $\begin{array}{c}\text { Ratio AR and } \\
\mathrm{Np}\end{array}$ & \begin{tabular}{|c|} 
Ratio MF and \\
$\mathrm{Np}$
\end{tabular} & \begin{tabular}{|c|}
$\begin{array}{c}\text { Pay-off of } \\
\text { the owners' } \\
\text { equity }\end{array}$ \\
\end{tabular} & $\begin{array}{c}\text { Ratio OWC } \\
\text { and } \mathrm{Np}\end{array}$ & $\begin{array}{c}\text { Ratio LTL } \\
\text { and Np }\end{array}$ & $\begin{array}{c}\text { Ratio STL } \\
\text { and Np }\end{array}$ & \begin{tabular}{|c} 
Ratio AP and \\
$\mathrm{Np}$
\end{tabular} & \begin{tabular}{|c|} 
Cost- \\
intensiveness of \\
net profit \\
\end{tabular} & \begin{tabular}{|c|}
$\begin{array}{c}\text { Revenue per } \\
1 \text { ruble of net } \\
\text { profit }\end{array}$ \\
\end{tabular} & \begin{tabular}{|c|} 
Ratio sales \\
profit and net \\
profit \\
\end{tabular} & \\
\hline 2.844 & 0.397 & 0.460 & 0.166 & 0.284 & 0.479 & 0.416 & 0.083 & 0.542 & 0.542 & 0.370 & 0.445 & 0.610 & * \\
\hline
\end{tabular}

1. Block describing the relationship between the final results of the company (P1, the lower small triangle).
Its value (1.752) suggests that net profit grows faster than sales profit. 
2. Block of converting assets, their sources and expenses into the income of the company (P2, the large rectangle). Its value (2.551) shows that the production efficiency increased 2.5 times.

3. Block of interrelation of expenses with assets and their sources (P3, lower rectangle located under the main diagonal of the matrix). The authors explain its use as an exception by the need to maximize the index compared to unity. The upper small rectangle could also be used, but its normal value should be less than one: expenses should grow more slowly than assets and their sources, which contradicts the output condition for determining the level of financial stability. This indicator value is 1.011 , which proves rapid growth of assets and their formation sources compared to the cost of the products sold by $1.1 \%$.

4. 4. Block of interrelation of the company's assets $(\mathrm{P} 4=$ 0.830 , upper small triangle) describes the decrease in the amount of accounts receivable in comparison with other assets (which is good) and the amount of monetary funds (which adversely affects the level of financial stability).

5. 5. Block of interrelation of all the sources of company's assets (P5 $=2.023$, middle triangle) indicates a large gap between the growth rate of shortterm liabilities and reduction rate of long-term liabilities.

6. 6. Block of interrelation of assets and their sources (P6 $=1.470$, middle rectangle) indicates the outstripping growth of short-term liabilities in terms of accounts payable over declining accounts receivable.

7. 7. The integral block of the interrelation of assets and their sources $(\mathrm{P} 7=(\mathrm{P} 4+\mathrm{P} 5+\mathrm{P} 6) / 3=1.441)$ shows the outstripping growth of individual sources of assets over their total sum and all funds (assets) of the company.

Under financially stable operation of the company, the value of blocks P1, P2 and P3 fluctuates at the level higher than 1 , and the value of block P7, together with P4, P5, P6, should be approximately equal to 1 . These statements are based on the principle 'costs - implementation - profit' and the 'gold economic rule'.

Hence it is clear that the generalizing indicator of financial stability (FSI - financial stability index) should be equal to or greater than 1, while in the case of an unstable financial situation of the company, the value of this indicator will be less than 1. In this regard, the generalizing indicator of the financial stability of a company (FSI) can be calculated as the arithmetic average of blocks of indicators P1, P2, P3, P7.

The resulting information of the matrix model for monitoring the financial sustainability of the company is summarized in Table 3.

$\mathrm{FSI}=(\mathrm{P} 1+\mathrm{P} 2+\mathrm{P} 3+\mathrm{P} 7) / 4=1.689$

This value shows stability of the company's operations.
The interpretation of the generalized value of the financial stability indicator for investment risk assessment in the agrarian sector is associated with the study of changes in FSIs over a number of years (from 3 to 5 or more) and is presented in Table 4.

In this regard, to determine the investment risk in the company in question, FSIs were calculated on the basis of the matrix model for three years. The resulting financial stability indicators are higher than 1 and clearly reflect the dynamics of development. Particularly, on 01.01.2012 FSI was 1.414, on 01.01.2013 it was 1.524, and on 01.01.2014-1.689.

TABLE III. INVESTMENT RISK ASSESSMENT IN AGRICULTURAL ARTEL 'RASSVET' BASED ON THE MATRIX MODEL

\begin{tabular}{|l|c|c|c|}
\hline \multicolumn{1}{|c|}{ Indicators } & Convention & $\begin{array}{c}\text { Value } \\
\text { calculated } \\
\text { for } \\
\text { 'Rassvet' }\end{array}$ & $\begin{array}{c}\text { Normal } \\
\text { value }\end{array}$ \\
\hline $\begin{array}{l}\text { The indicator of the relationship } \\
\text { between the final results }\end{array}$ & P1 & 1.752 & $>1$ \\
\hline $\begin{array}{l}\text { The indicator of converting assets, } \\
\text { their sources and expenses into the } \\
\text { income of the company }\end{array}$ & P2 & 2.551 & $>1$ \\
\hline $\begin{array}{l}\text { The indicator of interrelation of } \\
\text { assets and their sources and the } \\
\text { company's expenses }\end{array}$ & P3 & 1.011 & $>1$ \\
\hline $\begin{array}{l}\text { The indicator of interrelation of the } \\
\text { company's assets }\end{array}$ & P4 & 0.830 & $\approx 1$ \\
\hline $\begin{array}{l}\text { The indicator of interrelation of the } \\
\text { sources of company's assets }\end{array}$ & P5 & 2.023 & $\approx 1$ \\
\hline $\begin{array}{l}\text { The indicator of interrelation of } \\
\text { assets and their sources }\end{array}$ & P6 & 1.470 & $\approx 1$ \\
\hline $\begin{array}{l}\text { The integral indicator of the } \\
\text { interrelation of assets and their } \\
\text { sources }\end{array}$ & P7 & 1.441 & $\approx 1$ \\
\hline $\begin{array}{l}\text { The indicator of financial stability of } \\
\text { the company }\end{array}$ & FSI & 1.689 & $\geq 1$ \\
\hline
\end{tabular}

TABLE IV. INVESTMENT RisK ASSESSMENT IN AGRICULTURAL SECTOR BASED ON THE DYNAMICS OF THE GENERALIZING INDICATOR OF FINANCIAL STABILITY

\begin{tabular}{|c|c|c|}
\hline $\begin{array}{c}\text { FSI value on the } \\
\text { report date }\end{array}$ & $\begin{array}{c}\text { Dynamics of FSI } \\
\text { change compared to the } \\
\text { previous report period }\end{array}$ & Investment risk \\
\hline$\geq 1$ & growth & low \\
\hline$\geq 1$ & reduction & moderate \\
\hline$\geq 1$ & stability & low \\
\hline$<1$ & growth & moderate \\
\hline$<1$ & reduction & high \\
\hline$<1$ & stability & high \\
\hline
\end{tabular}

Based on these calculations, it should be concluded that there is the possibility of investing in this company at low risk level.

It is important to note that determination of the financial stability level of a company is the core of the matrix model. The matrix model of tracking changes in the financial stability of a company provides revealing its activities from various angles. This is a unique system of indicators that continuously reflect the operation quality and methods. It provides an assessment of the results of decisions made and actions of managers at various levels, the measure of control and management of assets, their sources, expenses and incomes of a company. This is important for the investor who has placed 
his money in the activities of a particular company. Besides, the matrix model helps identifying the first signs of inefficient operation of a company, affecting the financial stability level, and to rank the organizations of the potential territory for capital investment in order to select a company with acceptable investment risk level.

The source of information forming the basis for FSI calculations is Form No. 1 'Accounting Balance' and No. 2 'Report on Profit and Loss' of the accounting (financial) statements.

Assessment of the investment risk and its study in the dynamics according the proposed method can be computerized. For this, one needs to use the Matrix Model for Monitoring the National Unitary Enterprise program, made using MS Visual Basic 6.3 and MS Excel 2003 [10].

\section{RESUlTS}

The order of the result presentation and evaluation does not present any special difficulties, since the resulting indicators are five indices, and the generalizing and key indicator is only one of them, but on its basis one can draw a conclusion about the risk level and trends of its change.

Thus, investment risk assessment in the agrarian sector based of the matrix model allows investors to identify in advance the agricultural organizations with high probability of the negative phenomena formation in the course of production and commercial activities and avoid unprofitable investments.

The flexibility of this procedure is that it allows one to establish and control the degree of investment risk in the activities of any economic entity with financial autonomy.

Obviously, the inflow of investments in the agrarian sector will bring about the following tasks:

1 procurement of additional sources of financing for developing agricultural organizations;

2 ensuring the sustainable functioning of companies in the agrarian sector;

3 development of new industries and improvement of existing ones, creation of additional jobs and increase in tax revenues;

4 growth of attractiveness of rural areas for the population;

5 improvement of the region's position as a whole in terms of social and economic development and investment attractiveness.
Systematization of work to improve the transparency of determination and tracking the investment risk in agriculture on the basis of the suggested matrix model with the standard ranked scale is a pledge and a basis for increasing the investment attractiveness of companies, that can ensure the dynamic social and economic development of rural areas and the agrarian sector of the country. On the other hand, the method developed by the authors for express - assessment of the investment risk in the agrarian sector can meet the needs of the Department of Agrarian Policy and Business in providing scientific and methodological support for ranking agricultural companies of the area in question to identify the dynamics of their development and the risk of investing in their activities.

\section{References}

[1] V.Antashov, G.Uvarova 'Balanced indicator system for assessment of a company's activity,' Economics and life, 2005, no. 28, p.7

[2] M.A.Volkova, E.D.Solomatina, N.V.Shabutskaya, T.V.Sabetova, E.A.Shubina, 'History of views on audit of commercial structures management quality', Contributions to Economics, 2017, no. 9783319454610, pp. 81-90.

[3] K. Kluza, 'Risk assessment of the local government sector based on the ratio analysis and the DEA method. Evidence from Poland', Eurasian economic review, 2017, vol.7, no. 3, pp. 329-351.

[4] H.V.Strokovych, O.P.Mykolenko, 'Formation of the system of assessments of the financial and investment potential of an enterprise', Financial and credit activity-problems of theory and practice, Vol.2, no. 25, pp.246-252.

[5] N.K. Avkiran, C.M. Ringle, R.Low, 'Monitoring transmission of systemic risk: application of partial least squares structural equation modeling in financial stress testing', Journal of Risk, Vol.20, no. 5, pp. 83-115.

[6] Y.Song, S.Yao, D.Yu, 'Risky multi-criteria group decision making on green capacity investment projects based on supply chain', Journal of business economics and management, 2017, vol. 18, no. 3, pp. 355-372.

[7] E.V.Zakshevskaya, T.V.Savchenko, T.V.Zakshevskaya, I.V.Rysikova, Y.A.Prosyannikova, 'Antirecessionary policy methods for agricultural enterprises on the cluster analysis basis', Research Journal of Pharmaceutical, Biological and Chemical Sciences, 2016, nol. 7, no. 4, pp. 2714-2720.

[8] Z.A. Krush, L.A.Zaporozhtseva 'Internal financial monitoring: matrix model', Economics og agricultural and processing companies, 2006, no. 10 , pp. $51-54$

[9] T.V.Savchenko, A.V.Ulezko, L.V.Kiyashchenko, V.V.Reimer, A.A.Tyutyunikov, N.V.Tkacheva, 'Forecasting the development of agriculture in the region on the basis of ARIMA model', International Journal of Pharmacy and Technology, 2016, vol. 8, no. 2, pp. 14069 14078.

[10] Certificate of authorship no. 2006611877, National intellectual property, patent trademark service of the Russian Federation. Software 'Matrix model for national unitary enterprise monitoring', applicant and copyright owner L.A.Zaporozhtseva, applicance date April 11 $1^{\text {th }}, 2006$, registration date May $31^{\text {st }}, 2006$, p. 1 